\title{
EVALUATION OF THE EFFECT OF THE SEED EXTRACT OF MORINGA OLEIFERA LAM OVER THE EFFICIENCY OF ORGANIC FILTERS IN WASTEWATER TREATMENT OF DAIRY CATTLE BREEDING
}

\author{
JOÃO P. FRANCISCO ${ }^{1}$, JONATHAS B. G. SILVA ${ }^{2}$, ODIR C. C. ROQUE ${ }^{3}$, ALEXANDRE \\ L. NASCENTES ${ }^{4}$, LEONARDO D. B. SILVA $^{5}$
}

\begin{abstract}
This study aimed to evaluate the effect of Moringa oleifera Lam extract on the removal of total solids (TS), total suspended solids (TSS) and chemical oxygen demand (COD), in different filter media for treating wastewater of dairy cattle breeding (DCW). The moringa seed extract was obtained by grinding $50 \mathrm{~g}$ of seeds in one liter of distilled water and, after passing the solution through a quantitative paper filter of 25 microns, $60 \mathrm{~mL}$ of the extract were added to wastewater from cattle breeding before the filtration process in organic filters made of thin coal, bamboo leaves, eucalyptus leaves, gliricidia branches and sawdust. This was followed by the completely randomized experimental design, adopting a factorial of $5 \times 2$. Aliquots of filtered effluent were collected and the total solids (TS) concentrations, total suspended solids (TSS) and chemical oxygen demand (COD) were determined. It was found that the increase in the efficiency of removal of COD and total solids can be attributed to the coagulating power of the moringa seed extract, wherein the filter medium with bamboo leaves presented the best performance, showing potential for use as alternative filter material in the primary treatment of DCW.
\end{abstract}

KEYWORDS: coagulant, fertigation, water treatment.

\section{AVALIAÇÃO DO EFEITO DO EXTRATO DE SEMENTES DE MORINGA OLEIFERA LAM NA EFICIÊNCIA DE FILTROS ORGÂNICOS NO TRATAMENTO DE ÁGUAS RESIDUÁRIAS DE BOVINOCULTURA DE LEITE}

RESUMO: Objetivou-se avaliar o efeito do extrato de Moringa oleifera Lam na remoção de sólidos totais (ST), sólidos em suspensão totais (SST) e demanda química de oxigênio (DQO), em distintos meios filtrantes, no tratamento da água residuária de bovinocultura de leite (ARB). O extrato de sementes de moringa foi obtido triturando-se $50 \mathrm{~g}$ de sementes em um litro de água destilada e, após passar a solução em papel de filtro quantitativo de $25 \mu \mathrm{m}$, foram adicionados $60 \mathrm{~mL}$ do extrato à água residuária de bovinocultura, antes do processo de filtração em filtros orgânicos constituídos por fino de carvão, folhas de bambu, folhas de eucalipto, ramos de gliricídia e serragem de madeira. Seguiu-se o delineamento experimental inteiramente aleatorizado, adotando um esquema fatorial de $5 \times 2$. Alíquotas do efluente filtrado foram coletadas, e determinaram-se as concentrações de sólidos totais (ST), sólidos em suspensão totais (SST) e demanda química de oxigênio (DQO). Verificou-se que o aumento na eficiência de remoção de sólidos totais e DQO pode ser atribuído ao poder coagulante do extrato de sementes de moringa, sendo que o meio filtrante com folhas de bambu apresentou melhor desempenho, demonstrando potencial de utilização como material filtrante alternativo no tratamento primário de ARB.

PALAVRAS-CHAVE: coagulante, fertirrigação, tratamento de água.

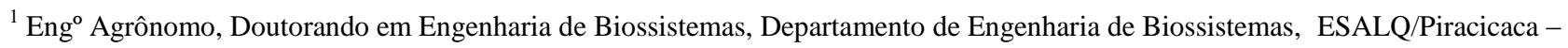
SP, Fone: (19) 3447-8556, jpbausen@usp.br.

${ }^{2}$ Eng $^{\circ}$ Agrícola e Ambiental, Prof. Doutor, Departamento de Engenharia Sanitária e Ambiental, UFJF/Juiz de Fora - MG, jonathasbsilva@gmail.com.

${ }^{3}$ Eng. Químico, Prof. Doutor, Departamento de Saúde e Saneamento Ambiental, FIOCRUZ/Rio de Janeiro - RJ.

${ }^{4}$ Eng $^{\circ}$ Civil, Prof. Doutor, Departamento de Engenharia, UFRRJ/Seropédica - RJ, lioi@ ufrrj.br.

${ }^{5}$ Eng $^{\circ}$ Agrícola, Prof. Doutor, Departamento de Engenharia, UFRRJ/Seropédica - RJ, monitoreambiental@ gmail.com. 


\section{INTRODUCTION}

The amount of waste produced daily by dairy cattle is a major problem in feedlots. According to CARVALHO \& SILVA (2006), in most feedlots with hydraulic cleaning waste systems, water consumption is of 200 to 250 liters per animal unit per day. According to these authors, the daily production of manure (feces + urine) in dairy cattle is about $10 \%$ of their body weight, which represents, in most cases, a production rate of $45-48 \mathrm{~kg}$ animal ${ }^{-1}$ day $^{-1}$. With regard to the qualitative characteristics of wastewater from dairy cattle breeding, it can be stated that the water is rich in organic matter, total solids and nutrients (ERTHAL et al., 2010).

The agricultural use of wastewater is an important contribution in minimizing the contamination of surface water by reducing its direct release, besides becoming an alternative source of nutrients through fertigation. However, because of the large amount of solid material in suspension present in these waters, there have been frequent problems with clogging of pumps, pipes, and above all emitters in irrigation systems (RAMIREZ, 2010). Therefore, it becomes necessary to execute a primary treatment to reduce the clogging risk during fertigation, especially if this is done by localized irrigation systems (LO MONACO et al, 2011).

The primary treatment of wastewater aims to remove solids and organic matter, in order to reduce values of Biochemical Oxygen Demand (BOD) and Chemical Oxygen Demand (COD) (BERTONCINI, 2008). Filtration is among the forms of primary treatment aimed at removing suspended solids.

Filters that utilize organic materials as filter elements have been tested and have shown satisfactory results, and the filter element can be replaced easily, solving the problem of high frequency of clogging. The use of alternative filter material from agriculture and cattle breeding activities is of great interest due to the abundance and low cost, and it can also be composted after filtration and used as agricultural fertilizer (MAGALHÃES et al., 2006a).

There are several solid wastes that can be used as filter material, naming sugar cane bagasse and wood sawdust (MATOS et al, 2010); coffee beans pergamino (LO MONACO et al, 2011); coconut fibers (LO MONACO et al , 2009); Cameroon grass (FRANCISCO et al, 2010); gliricidia and bamboo leaves (FRANCISCO et al, 2011a). With the use of organic filters in the primary treatment of swine breeding wastewater, removal efficiencies higher than $60 \%$ for total solids (LO MONACO et al., 2009), 75\% for total suspended solids (LO MONACO et al. 2009), 40 and 80\% for COD and BOD, respectively, have been achieved (LO MONACO, 2004).

The moringa seeds (Moringa oleifera Lam) are used as natural coagulant and have been used successfully in removing suspended solids from turbid waters, even replacing the aluminum sulphate (CRUZ et al, 2007).

Moringa oleifera is a tropical plant belonging to the family of Moringaceae, which features coagulant properties in its seeds. According to NDABIGENGESERE et al. (1994) the coagulant action of moringa seeds is attributed to the presence of water-soluble cationic proteins, and only the dried seeds which reached physiological maturity have the coagulant properties. MATOS et al. (2007) reported the removal of turbidity higher than $90 \%$ in the $\mathrm{pH}$ range from 4.0 to 5.0 and doses of $10 \mathrm{~mL} \mathrm{~mL}^{-1}$. PATERNIANI et al. (2009) found that the coagulant solution obtained from the Moringa oleifera seeds is effective to treat water with turbidity ranging from 50 to 100 NTU, both by simple sedimentation and slow filtration on non-synthetic fabric.

Given the above, the objective was to evaluate the effect of Moringa oleifera Lam extract on the removal of total solids, total suspended solids and chemical oxygen demand in different filtering media to treat wastewater from dairy cattle breeding. 


\section{MATERIAL AND METHODS}

The experiment was conducted at the Laboratory of Hydraulics and Irrigation of the Engineering Department, Federal Rural University of Rio de Janeiro (UFRRJ) and at the Laboratory of the Department of Public Health and Sanitation (DSSP), National School of Public Health (ENSP), located at the Oswaldo Cruz Foundation, Rio de Janeiro (FIOCRUZ).

Wastewater from dairy cattle breeding (DCW), obtained from the stable of the Integrated Agroecological Production System (SIPA) was used. The cleaning system of the SIPA stable works by scraping manure and subsequent applying water to the floor.

The wastewater was stored in a box of 100 liters, where it remained in the sedimentation process for 24 hours before starting the filtration. The characterization of the DCW was performed at the Laboratory of the Department of Sanitation and Public Health, where concentrations of total solids (TS), total suspended solids (TSS), chemical oxygen demand (COD) and $\mathrm{pH}$ were analyzed, according to the methods recommended by APHA (2005). Table 1 presents the characteristics of the DCW used in the experiment after the sedimentation process.

TABLE 1. Characterization of wastewater from dairy cattle breeding used in the experiment, obtained from the stable of the Integrated Agroecological Production System (SIPA) after sedimentation.

\begin{tabular}{lcc}
\hline Characteristics & Average Value & Standard Deviation \\
\hline Total Solids $\left(\mathrm{mg} \mathrm{L}^{-1}\right)$ & 2884 & 544 \\
Total Suspended Solids $\left(\mathrm{mg} \mathrm{L}^{-1}\right)$ & 1339 & 377 \\
Oxygen Chemical Demand $\left(\mathrm{mg} \mathrm{L}^{-1}\right)$ & 3137 & 875 \\
$\mathrm{pH}$ & 7.2 & - \\
\hline
\end{tabular}

The filtration columns were assembled from PVC pipes of $100 \mathrm{~mm}$ in diameter and 1 meter in length, as described by Francisco et al. (2011c). Thin coal, bamboo leaves, eucalyptus leaves, Gliricidia branches and sawdust were used as filtering materials. The filtering materials were air dried, crushed into electrical mincer, and later sieved, so as to use only those materials that had size range between 2 and $3 \mathrm{~mm}$, as recommended by LO MONACO et al. (2004).

The completion of the filtration columns was done gradually, in layers of $10 \mathrm{~cm}$ under compression of $10706 \mathrm{~N} \mathrm{~m}^{-2}$, until it reached the height of $50 \mathrm{~cm}$. This pressure value was determined by calculating the pressure exerted by a man with $60 \mathrm{kgf}$ of weight supported on one foot.

In order to prevent the superficial sealing and the passage of particles from the means to the effluent, $10 \mathrm{~cm}$ layers of the filtering material have been added, with size range between 3 and 5 $\mathrm{mm}$, at the upper and lower ends of the filter, respectively. Figure 1 presents an illustration of the filter made. 


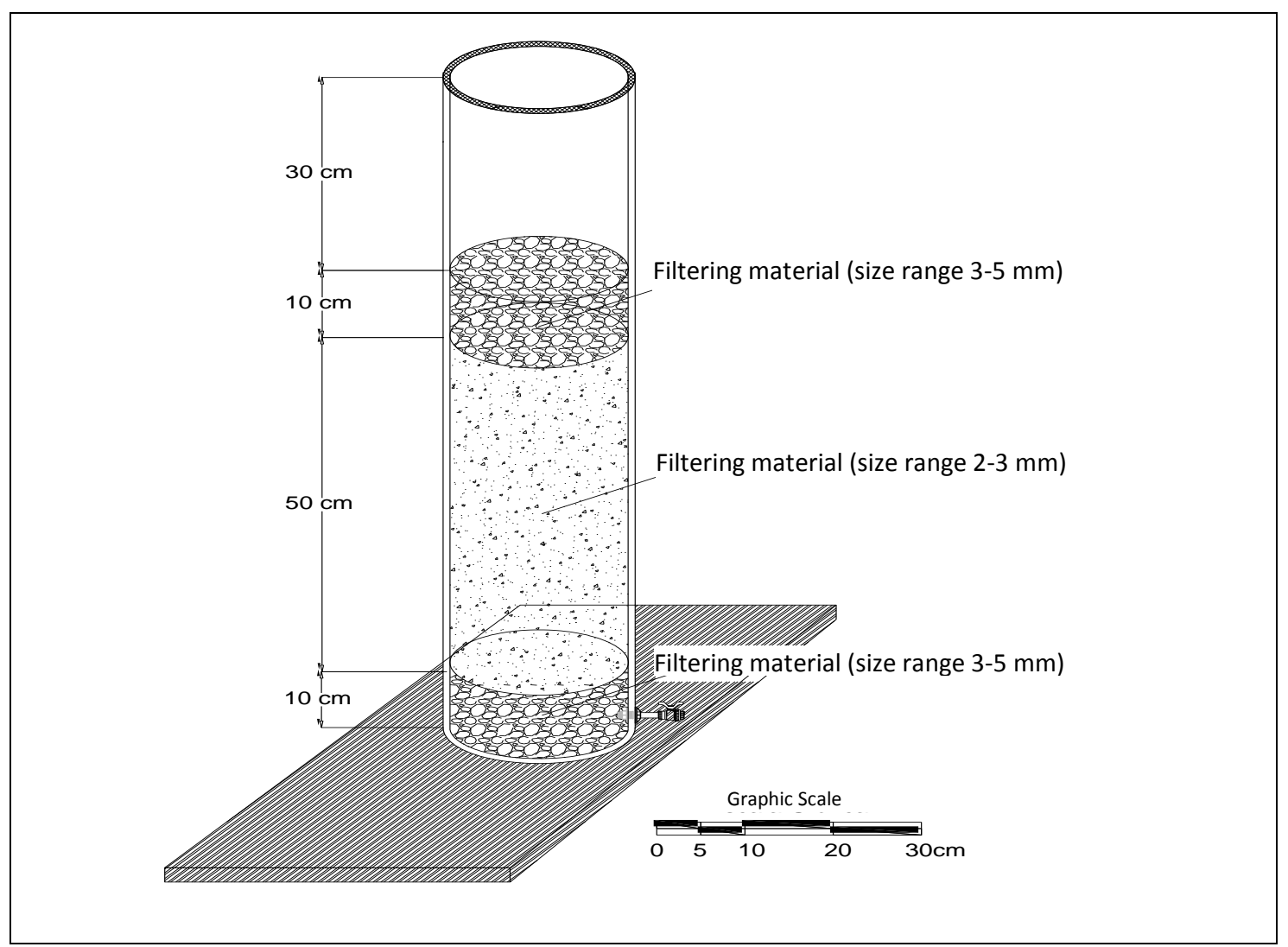

FIGURE 1. Illustration of the filter made.

Before filtration of wastewaters, we proceeded to washing the filter in order to remove solid particles that could be released by the filtering material and cause contamination of the effluent, as recommended by MATOS et al (2010).

Table 2 shows the values of specific particle mass $\left(\rho_{p}\right)$, density $(\rho)$, porosity $(P)$ and pore volume (PV) of each filtering material evaluated.

TABLE 2. Specific particle mass $\left(\rho_{p}\right)$, density $(\rho)$, porosity $(P)$ and pore volume $(P V)$ of the filtering materials.

\begin{tabular}{|c|c|c|c|c|}
\hline Filtering Material & $\rho_{p}$ & $\rho$ & $\mathrm{P}$ & PV \\
\hline & \multicolumn{2}{|c|}{$\mathrm{g} \mathrm{cm}^{-3}$} & $\mathrm{~cm}^{3} \mathrm{~cm}^{-3}$ & $\mathrm{~cm}^{3}$ \\
\hline thin coal & 0.93 & 0.315 & 0.661 & 2596 \\
\hline bamboo leaves & 0.78 & 0.169 & 0.783 & 3076 \\
\hline eucaliptus leaves & 0.83 & 0.196 & 0.763 & 2999 \\
\hline gliricidia branches & 0.48 & 0.151 & 0.685 & 2691 \\
\hline wood sawdust & 0.80 & 0.277 & 0.650 & 2552 \\
\hline
\end{tabular}

The Moringa oleifera Lam seeds were obtained from the campus of UFRRJ, and only the pods that had reached full physiological maturity were harvested. After harvested, the seeds were removed from the pods and dried in oven at $45^{\circ} \mathrm{C}$ for 24 hours. The moringa extract was prepared by grinding $50 \mathrm{~g}$ of seeds in one liter of distilled water and then filtering the solution on quantitative filter paper of $25 \mu \mathrm{m}$ (MENDES \& COELHO, 2007). $60 \mathrm{~mL}$ of the extract of $50 \mathrm{~g} \mathrm{~L}^{-1}$ were added for each liter of wastewater from cattle breeding, as recommended by FRANCISCO et al. (2011b). The mixture remained in manual stirring with the aid of a PVC tube with a length of 2.0 meters and an external diameter of $13.5 \mathrm{~mm}$ for 10 minutes, and the filtration process was performed right after. This procedure was adopted so that the extract could react with the residual water inside the 
filter, agglutinating the particulates so that they would be trapped in the pores and, once agglutinated, could have larger diameters than the diameters of the filter pores, allowing an increase in the efficiency of organic filters.

Before the start of filtration with DCW, 10 liters of clean water were applied to the filters, the objective of this procedure was to eliminate as many solid particles as possible, from the different filtering materials. The volume of DCW filtrated in each filter corresponded to five pore volumes and aliquots of $500 \mathrm{ml}$ were collected each time a corresponding pore volume of the filter medium (Table 2) was filtered. The filtration rate during the tests remained above $0.2 \mathrm{~L} \mathrm{~m}^{-2} \mathrm{~s}^{-1}$, as recommended by Matos et al. (2010), since from that point on the sealing of the filter occurs and then it is necessary to change the filtering material. The aliquots collected were stored at $4{ }^{\circ} \mathrm{C}$ and sent to the FIOCRUZ laboratory, where the concentrations of TS, TSS and COD were determined, according to the methods presented by APHA (2005).

The design was completely randomized, considering a factorial of $5 \times 2$, five filtering mediums, absence and presence of moringa and four repetitions, totaling 40 experimental plots. The data obtained were subjected to the analysis of variance and the averages were compared using the Tukey Test at $5 \%$ significance. Statistical analysis was performed with the aid of software SISVAR (FERREIRA, 2011).

\section{RESULTS AND DISCUSSION}

Table 3 presents the average removal efficiency of ST from the wastewater of dairy cattle breeding in the absence and presence of moringa seed extract, for each filtering material evaluated.

TABLE 3. ST removal efficiency of the different filtering medium evaluated, considering the absence and presence of Moringa oleifera seed extract in wastewater from cattle breeding.

\begin{tabular}{ccc}
\hline Treatments & Extract absence (\%) & Extract presence (\%) \\
\hline Eucalyptus & $18.92 \mathrm{cB}$ & $35.23 \mathrm{aA}$ \\
Sawdust & $24.24 \mathrm{bcB}$ & $40.81 \mathrm{aA}$ \\
Coal & $32.77 \mathrm{abA}$ & $40.28 \mathrm{aA}$ \\
Gliricidia & $32.91 \mathrm{abA}$ & $39.36 \mathrm{aA}$ \\
Bamboo & $33.92 \mathrm{aB}$ & $44.60 \mathrm{aA}$ \\
\hline
\end{tabular}

* means followed by at least one of the same small letter in the column and capital on the line do not differ from each other at $5 \%$ probability level by the Tukey Test.

The removal efficiency of ST in the effluents collected in filtration columns containing bamboo leaves, gliricidia and coal showed similar behavior to that found by MAGALHÃES et al. (2006b), who obtained ST removals of 31 to $56 \%$ when they used the sugar cane bagasse as filtering material in the treatment of swine breeding wastewater. Higher removals were found by LO MONACO et al. (2004), who obtained ST removal values of 60 to $70 \%$ in swine breeding wastewater without using the sedimentation process before filtration, when wood sawdust was used as filtering material. The use of eucalyptus leaves as filtering material resulted in the lowest ST removal efficiency, in the absence of moringa extract, which may have occurred due to the displacement of the material itself during the filtration process. Such behavior could be observed due to the change in color of the effluent, which after the filtration process began to show a reddish color. LO MONACO et al. (2011) observed an increase in the ST concentration in the affluent of wastewater from swine breeding due to the contribution of solids from the coffee straw used as filtering material. The same result was observed by Brandão et al. (2000), who found the increase of solids in swine breeding wastewater passed through organic filter consisting of sawdust and sugar cane bagasse.

As noted in Table 3, when the moringa seed extract is added in wastewater, higher average values of removal were reached compared to the absence of the extract, in the filters consisting of 
eucalyptus leaves, sawdust and bamboo. The increase in the removal efficiency of total solids can be attributed to the coagulating power of the moringa seed extract, since there was agglutination of the solid particles present in the wastewater, increasing its size and making it difficult for it to traverse the filter pores.

It was also observed that the filters consisting of eucalyptus leaves and sawdust were the ones which showed the lowest removal efficiencies, when compared to those composed of bamboo leaves. Such behavior may be associated with the entrainment of particles from the filter medium to the effluent and also with the lower porosity of the medium, as seen in Table 2. MAGALHÃES et al. (2005) found that the increase in the compression of the filtering material can increase the removal efficiency of solids, however excessive compression causes a significant reduction in porosity and hence of the permeability of these materials.

Table 4 shows the average removal efficiency of TSS in the absence and presence of the moringa seed extract.

TABLE 4. TSS removal efficiency for the different filter medium evaluated, considering the absence and presence of the Moringa oleifera seed extract in wastewater from cattle breeding.

\begin{tabular}{ccc}
\hline Treatments & Extract absence (\%) & ixtract presence (\%) \\
\hline Eucalyptus & $51.67 \mathrm{abA}$ & $47.44 \mathrm{aA}$ \\
Sawdust & $48.51 \mathrm{bA}$ & $36.88 \mathrm{aA}$ \\
Coal & $54.58 \mathrm{abA}$ & $46.87 \mathrm{aA}$ \\
Gliricidia & $61.25 \mathrm{abA}$ & $49.06 \mathrm{aB}$ \\
Bamboo & $63.94 \mathrm{aA}$ & $49.23 \mathrm{aB}$ \\
\hline
\end{tabular}

* means followed by at least one of the same small letter in the column and capital on the line do not differ from each other at $5 \%$ probability level by the Tukey Test.

The use of moringa seed extract caused a decline in the efficiency of TSS removal in filters consisting of Gliricidia leaves and bamboo leaves. According to RIBEIRO et al. (2009), the moringa seeds can increase the concentration of suspended solids in the wastewater. According to MATOS et al. (2007), increases in TSS removal efficiencies using moringa seed in wastewaters of agricultural industries can only be observed when using lower concentrations of extract inferior to $10 \mathrm{~mL} \mathrm{~L}^{-1}$ (with extract prepared with $30 \mathrm{~g}$ of seeds in $1 \mathrm{~L}$ of water) $\mathrm{pH}$ range being between 4.0 and 5.0. Therefore the concentration of $60 \mathrm{~mL} \mathrm{~L}^{-1}$ (extract prepared with $50 \mathrm{~g}$ of seeds in $1 \mathrm{~L}$ of water), which was added to wastewater from dairy cattle breeding promoted an increase in suspended solids in the effluent, resulting in no increase in the efficiency of TSS removal from the organic filters. Similar results were found by LO MONACO et al. (2010) when evaluating the efficiency of different concentrations of moringa seed extract as a coagulant in treating swine breeding wastewater, observed that besides moringa not having contributed to the coagulation process, the organic matter from the seeds contributed to the increase in suspended solids in the water. MENDES et al. (2010) found that the increase in the concentration of the moringa seed extract results in increased suspended solids in wastewater.

It is noted that the $\mathrm{pH} 7.2$ of wastewater used during the tests differ from the range recommended by MATOS et al. (2007) and that this condition may have influenced the effect of the moringa extract on TSS removal, since chitosan, cationic polysaccharide that brings the coagulating power of Moringa seeds, only has high coagulation power at $\mathrm{pH}<6.5$ (KIMURA et al. 1999). Another explanation for the decrease in removal efficiency is related to the fact that the filtration process of wastewater from cattle breeding was initiated 10 minutes after the addition of moringa extract. According to CABANELLAS (2004), the minimum time required to achieve efficiency of 60 to $90 \%$ removal of TSS from wastewater of coffee pulping must be greater than 120 minutes due to the slow rate of coagulation of the solids. 
Table 5 presents the average removal efficiency of COD in the absence and presence of the moringa seed extract.

TABLE 5. COD removal efficiency from the different filter media evaluated, considering the absence and presence of Moringa oleifera seed extract in cattle breeding wastewater.

\begin{tabular}{ccc}
\hline Treatments & Extract absence (\%) & Extract presence (\%) \\
\hline Eucalyptus & $3.71 \mathrm{bB}$ & $30.00 \mathrm{aA}$ \\
Sawdust & $20.22 \mathrm{abA}$ & $30.12 \mathrm{aA}$ \\
Coal & $21.08 \mathrm{abA}$ & $28.00 \mathrm{aA}$ \\
Gliricidia & $25.47 \mathrm{aA}$ & $34.59 \mathrm{aA}$ \\
Bamboo & $27.62 \mathrm{aB}$ & $43.38 \mathrm{aA}$ \\
\hline
\end{tabular}

* means followed by at least one of the same small letter in the column and capital on the line do not differ from each other at $5 \%$ probability level by the Tukey Test

The filtering materials showed COD removal efficiency below the values found by LO MONACO et al. (2004), who obtained $80 \%$ removal using sawdust as filtering material and using the settling process following filtration. According to LO MONACO et al. (2004), filtering materials with small particle size range between, 2 to $3 \mathrm{~mm}$, in view of their higher specific surfaces, allow for greater swill of the material, contributing to the leaching of organic material, which promote the increase of the COD values in the effluent of the filters. The filters filled with eucalyptus leaves confirmed the assertion of LO MONACO et al. (2004), since they released organic materials to the effluent, resulting in low COD removal efficiency of this filtering material in the absence of moringa seed extract in DCW.

The addition of moringa seed extract in cattle breeding wastewater promoted increase in COD removal efficiency of organic filters made of eucalyptus leaves and bamboo leaves. The determined results differ from those obtained by VAZ (2007), who observed an increase of COD in wastewater using moringa seeds. The results found may be explained by the difference in concentration of the extract used when comparing two studies, since VAZ (2007) used the extract at a concentration of 10 grams of seed per liter of distilled water.

The increase in removal efficiency of total solids and COD can be attributed to the coagulant power of the moringa seed extract, as there was agglutination of the solid particles present in the wastewater, increasing its size and making it difficult to traverse the filter pores. The same efficiency was not observed in TSS removal, since the concentration of moringa seed extract and the $\mathrm{pH}$ of wastewater from dairy cattle breeding was not in the range recommended by other authors (BOREM, 2008 \& MATOS et al. 2007), as well as the particle size range used, which did not favor the removal of TSS (MAGALHÃES et al., 2006b)

Based on these results, there was good efficiency of the organic materials used as filtering elements, indicating that they may be used in the primary treatment of DCW, which would facilitate the use of this effluent in fertigation of crops interesting for the rural producer, reducing maintenance costs of the filters used in irrigation systems. The bamboo leaf was the best filtering media that presented results from removal of TS, TSS and COD, such behavior may be associated with higher porosity of the filter media, when compared to other materials. The use of moringa extract as a coagulant agent provided an increase of TS and COD removals, indicating to be an alternative in wastewater treatment. However, it was found that only the sedimentation processes, coagulation with moringa extract and filtering with the filtering media evaluated were not sufficient to remove the solids present in the DCW to the point of meeting the satisfactory standards for irrigation. According to NAKAYAMA \& BUCKS (1991), the use of water with suspended solids concentration greater than $100 \mathrm{mg} \mathrm{L}^{-1}$ present a severe clogging risk in localized irrigation systems. Therefore, there is a need for further studies to develop technologies in order to enable the use of wastewater in agricultural areas, without the risk of damage to the physical environment or the irrigation system. 


\section{CONCLUSIONS}

1 - The use of the moringa seed extract contributed to the increase in the efficiency of organic filters, for the filter media analyzed, in the ST and COD removal during the filtration process of cattle breeding wastewater, but did not increase the efficiency of SST removal.

2 - Comparing the different filter media analyzed, it is observed that the filtering medium with bamboo leaves performs better, demonstrating potential to be used as alternative filter material in the primary treatment of DCW.

\section{REFERENCES}

APHA - American Public Health Association. Standard methods for the examination of water and wastewater. 21. ed. Washington, DC: APHA, 2005. 1600p.

BERTONCINI, E. I. Tratamento de efluentes e reuso da água no meio agrícola. Revista Tecnologia \& Inovação Agropecuária, São Paulo, v.1, n.1, p.152-169, 2008.

BOREM, F. M. Processamento do café: In: BOREM, F. M., Pós-colheita do Café, Lavras: Ed. UFLA, 2008.

BRANDÃO, V. S. MATOS, A. T.; MARTINEZ, M. A.; FONTES, M. P. P. Tratamento de águas residuárias de suinocultura utilizando-se filtros orgânicos. Revista Brasileira de Engenharia Agrícola e Ambiental, Campina Grande, v. 4, n. 3, p. 327-333, 2000.

CABANELLAS, C. F. G. Tratamento da água sob recirculação, em escala laboratorial, na despolpa dos frutos do cafeeiro. Engenharia Agrícola, Jaboticabal, p. 31- 33, 2004.

CARVALHO, H. P.; SILVA, I. J. O. Metais pesados presentes na água residuária de sistema de exploração leiteira Do tipo "freestall”. Revista Eletrônica Thesis, São Paulo, v. 6, p. 1-8, 2006.

CRUZ, M. W. O.; OLIVEIRA, E. G. O.; ARAÚJO FILHO, J. M.; HIPÓLITO, L. F.; LIMA, C. B. Avaliação da eficiência de sementes de moringa no tratamento de efluentes de viveiros de camarão marinho. Rev. Ciência Agronômica, Fortaleza, v.38, n.3, p.257-263, 2007.

ERTHAL, V. J. T.; FERREIRA, P. A.; PEREIRA, O. G; MATOS, A. T. Características fisiológicas, nutricionais e rendimento de forrageiras fertigadas com água residuária de bovinocultura. Rev. Brasileira de Engenharia Agrícola e Ambiental, Campina Grande, v.14, n.5, p.458-466, 2010.

FERREIRA, D. F. Sisvar: a computer statistical analysis system. Ciência e Agrotecnologia, Lavras, v. 35, p. 1039-1042, 2011.

FRANCISCO, J. P.; ALMEIDA, W. S.; RIBEIRO, R. R.; CARVALHO, D. F.; BATISTA DA SILVA, L. D. Utilização de filtros orgânicos no tratamento primário de águas residuárias de bovinocultura. In: CONGRESO LATINOAMERICANO Y DEL CARIBE DE INGENIERÍA AGRÍCOLA, 9.; CONGRESSO BRASILEIRO DE ENGENHARIA AGRÍCOLA, 39., 2010, Vitória, Anais... Vitória: Associação Brasileira de Engenharia Agrícola, 2010. 1CD-ROM.

FRANCISCO, J. P.; SILVA, J. B. G.; BATISTA DA SILVA, L. D.; LIOI, A. N.; BARBOSA, K. P. Remoção de sólidos totais de água residuária de bovinocultura utilizando-se filtros orgânicos. In: CONGRESSO BRASILEIRO DE ENGENHARIA AGRÍCOLA, 40. 2011a, Cuiabá, Anais...

Cuiabá: Associação Brasileira de Engenharia Agrícola, 2011a. 1CD-ROM.

FRANCISCO, J. P.; BATISTA DA SILVA, L. D; SILVA, J. B. G.; VELASCO, T. S.; SILVA, R. B. Uso do extrato de semente de moringa na floculação do material em suspensão presente na água 
residuária da bovinocultura In: WORD WATER CONGRESS, 49. 2011b, Porto de Galinhas, Anais... 1CD-ROM.

FRANCISCO, J. P. LANA, L. O.; BRANDÃO, R. S.; SILVA, J. G. B.; BATISTA DA SILVA, L. D. Desempenho de filtros orgânicos no tratamento de água residuária de bovinocultura de leite. Cadernos de Agroecologia, Porto Alegre, v. 6, n. 2, dez. 2011c.

KIMURA, I. Y.; GONÇALVES, A. C.; STOLBERG, J.; LARANJEIRA, M. C M ; FÁVERE, V. T. Efeito do $\mathrm{pH}$ e do tempo de contato na adsorção de corantes reativos por microesferas de quitosana. Polímeros, São Paulo, n.3, p. 51-57, 1999.

LO MONACO, P. A.; MATOS, A. T. JORDÃO, C. P.; CECON, P. R Desempenho de filtros constituídos por fibras de coco no tratamento de águas residuárias de suinocultura. Engenharia na Agricultura, Viçosa, MG, v. 17, n. 6, p. 473-480, nov./dez. 2009

LO MONACO, P. A.; MATOS, A. T.; JORDÃO, C. P.; CECON, P. R.; MARTINEZ, M. A. Influência da granulometria da serragem de madeira como material filtrante no tratamento de águas residuárias. Revista Brasileira de Engenharia Agrícola e Ambiental, Campina Grande, v.8, n.1, p.116-119, 2004.

LO MONACO, P. A. V.; MATOS, A. T.; RIBEIRO, I. C. A.; NASCIMENTO, F. S.; SARMENTO, A. P. Utilização de extrato de sementes de moringa como agente coagulante no tratamento de água para abastecimento e águas residuárias. Revista Ambiente e Água, Taubaté, v.5, n.3, 2010.

LO MONACO, P. A. V.; MATOS, A. T. JUNIOR, V. E.; SARMENTO, A. P.; MOREIRA, R. M. G. Desempenho de filtros constituídos por pergaminho de grãos de café (Coffea sp.) no tratamento de águas residuárias. Coffee Science, Lavras, v. 6, n. 2, p. 120-127, maio/ago. 2011.

MAGALHÃES, M. A.; MATOS, A. T.; AZEVEDO, R. F.; DENICULI, W. Influência da compressão no desempenho de filtros orgânicos para tratamento de águas residuárias da suinocultura. Engenharia na Agricultura, Viçosa, MG, v.13, n.1, p.26-32, 2005.

MAGAlhãES, M. A.; MATOS, A. T.; DENICULI, W.; TINOCO, I., F., F. Compostagem de bagaço de cana-de-açucar triturado utilizado como material filtrante de águas residuárias de suinocultura. Revista Brasileira de Engenharia Agrícola e Ambiental, Campina Grande, v.10, n.2, p.466-471, 2006a.

MAGAlHÃES, M. A.; MATOS, A. T.; DENICULI, W.;TINOCO, I. F. F. Operação de filtros orgânicos utilizados no tratamento de águas residuárias de suinocultura. Revista Brasileira de Engenharia Agrícola e Ambiental, Campina Grande, v.10, n.2, p.472-478, 2006b.

MATOS, A. T.; MAGALHÃES, M. A.; FUKUNAGA, D. C. Remoção de sólidos em suspensão na água residuária da despolpa de frutos do cafeeiro em filtros constituídos por pergaminho de grãos de café submetido a compressões. Revista Engenharia Agrícola, Jaboticabal, v.26, n.2, p.610-616, maio/ago. 2006.

MATOS, A. T.; CABANELLAS, C. F. G.; CECON, P. R.; BRASIL, M. S.; MUDADO, C. S. Efeito da concentração de coagulantes e do ph da solução na turbidez da água, em recirculação, utilizada no processamento dos frutos do cafeeiro. Revista Engenharia Agrícola, Jaboticabal, v.27, n.2, p.544-551, 2007.

MATOS, A. T.; MAGALHAES, M. A. SARMENTO, A. P. Perda de carga em filtros orgânicos utilizados no tratamento de água residuária de suinocultura. Revista Engenharia Agrícola, Jaboticabal, v.30, n.3, p.527-537, 2010. 
MENDES, M. F.; COELHO, N.M.M. Estudo do uso da Moringa oleifera para remoção de prata e manganês em águas. Horizonte Científico, Uberlândia, v.1, n.1, p.1-18, 2007.

MENDES, M. A. S. A.; SOUZA, T. D.; MATOS, A. T.; LO MONACO, P. A. V. Avaliação do efeito coagulante do extrato de semente de moringa oleifera para separação de microalgas das água. In: CONGRESSO BRASILEIRO DE ENGENHARIA AGRÍCOLA, 40. 2011a, Cuiabá, Anais... Cuiabá: Associação Brasileira de Engenharia Agrícola, 2011a. 1CD-ROM.

NAKAYAMA, F.S.; BUCKS, D.A. Water quality in drip/trickle irrigation: A review. Irrigation Science, New York, v.12, p.187-92, 1991.

NDABIGENGESERE, A.; NARASIAH, K.S.; TALBOLT, B.G. Active agents and mechanism of coagulation of turbid waters using Moringa oleifera. Water Research, Londres, v.29, n.2, p.703-10, 1994.

PATERNIANI, J. E. S.; MANTOVANI, M. C.; SANT'ANNA, M. R. Uso de sementes de Moringa oleifera para tratamento de águas superficiais. Revista Brasileira de Engenharia Agrícola e Ambiental, Campina Grande, v.13, n.6, p.765-771, 2009.

RAMIREZ, J. C. S. Efeito das características granulométricas e da altura da camada filtrante no processo de retrolavagem em filtros de areia. 2010. 159f. Dissertação (Mestrado) - Universidade Estadual de Campinas, Campinas, 2010.

RIBEIRO, I. C. A.; LO MONACO, P. A. V.; NASCIMENTO, F. S.; SILVA, R. A.; MATOS, A. T.; SARMENTO, A. P. Utilização extrato de sementes de moringa como agente coagulante natural no tratamento da água residuária de suinocultura. In: SIMPÓSIO DE INICIAÇÃO CIENTÍFICA, 2009, Viçosa. Anais... Viçosa: UFV, 2009.

VAZ, L. G. L. Performance do processo de coagulação/floculação no tratamento do efluente líquido gerado na galvanoplastia. 2007. 100f. Dissertação (Mestrado em Engenharia Química) Universidade Estadual do Oeste Paraná, Curitiba, 2007. 